\title{
HIVIAIDS IN THE WORKPLACE AND THE IMPACT ON FIRM EFFICIENCY AND FIRM COMPETITIVENESS: The SOUTH African MANUfaCtURING INDUSTRY AS A CASE STUDY
}

Authors:

Gerhardus van Zy ${ }^{1}$

Carol Lubisi

\section{Affiliations:}

${ }^{1}$ Department of Economics \& Econometrics, University of Johannesburg,

South Africa

Correspondence to:

Gerhardus van Zyl

e-mail:

hardusvz@uj.ac.za

\section{Postal address:}

PO Box 10152

Aston Manor, 1630,

South Africa

Keywords:

HIV/AIDS; efficiency;

labour productivity; skills

levels; econometric

log-linear power functions

Dates:

Received: 18 Mar. 2009

Accepted: 21 Aug. 2009

Published: 23 Oct. 2009

How to cite this article: Van Zyl, G., \& Lubisi, C. (2009). HIV/AIDS in the workplace and the impact on firm efficiency and firm competitiveness: The South African manufacturing industry as a case study. $S A$ Journal of Human Resource Management/SA Tydskrif vir Menslikehulpbronbestuur, 7(1), Art. \#206, 14 pages. DOI: 10.4102/sajhrm.v7i1.206

\section{This article is available}

http://www.sajhrm.co.za

(C) 2009. The Authors. Licensee: OpenJournals

Publishing. This work is licensed under the Creative Commons Attribution License

\section{ABSTRACT}

The aim of the article was to determine the extent of the negative impact of HIV/AIDS in the workplace on firm efficiency and firm competitiveness. The South African manufacturing sector was used as a case study. The above-mentioned research was deemed necessary, as very limited research has been published specifically on the technical measuring of the extent of the impact of HIV / AIDS on firm efficiency and firm competitiveness in South Africa. A survey questionnaire was designed for use in the research in order to capture the extent of the impact of HIV / AIDS on all levels of firm efficiency and firm competitiveness. A detailed statistical analysis of the results of the survey questionnaire and the parameter estimates of impact log-linear econometric power functions indicated that the negative impact of HIV/AIDS on firm efficiency and firm competitiveness was becoming more prevalent and serious, as it is underpinned by the statistical significance of the results and the high elasticity coefficients of the estimated log-linear power functions. It is recommended that human resource managers implement and manage HIV/ AIDS programmes more effectively in order to counter the extent of the negative impact on firm efficiency and firm competitiveness.

\section{INTRODUCTION}

The aim of this research was to determine the extent of the negative impact of HIV and AIDS on firm efficiency and firm competitiveness. The South African manufacturing industry was used as a case study. For the purposes of this article the impact of HIV/AIDS on firm efficiency is measured by changes in the quality and cost of labour (Call \& Holahan, 1983), while the impact of HIV/AIDS on firm competitiveness is based on profitability indicators (Masuku, 2005). In order to measure the extent of the impact of HIV / AIDS on firm efficiency and firm competitiveness, four hypotheses were tested and statistically validated, namely:

- the perceived wide existence of HIV/AIDS programmes in the manufacturing sector of the economy (irrespective of the size of the firms in this sector)

- the perceived high level of negative impacts of HIV / AIDS on skills levels in the workplace and on productivity-related components of firm efficiency levels

- the perceived high level of negative impacts of HIV/AIDS on labour and production costs

- the perceived high level of negative impacts of HIV/AIDS on firm competitiveness (as measured by profits, prices and sales).

In order to derive measurement categories that would effectively measure the extent of the negative impacts of HIV/AIDS on firm efficiency and firm competitiveness in the manufacturing sector of the South African economy, a detailed literature study was undertaken. Firstly, it was envisaged that the literature study would enhance an understanding of the magnitude of HIV/AIDS prevalence rates and the necessity for the private sector to implement HIV/AIDS programmes, and show how the extent of the implementation or non-implementation of HIV / AIDS programmes has impacted on firm efficiency. Secondly, the literature study would enable the researchers to determine the link between HIV / AIDS prevalence rates and skill levels, productivity levels, managerial efficiency, operating costs and profitability indicators.

\section{HIV/AIDS prevalence rates and the implementation of HIV/AIDS programmes in the private sector}

A study conducted by Cleary, Boulle, Castillo-Riquelme and McIntyre (2008) on the burden of HIV/ AIDS in the public health care system indicated that the HIV / AIDS pandemic in South Africa influences all spheres of the economy and society as a whole, impacting on macroeconomic, microeconomic, social and psychological levels. The same study also concluded that the provision of public health care for HIV / AIDS patients is under severe pressure as a result of funding constraints, shortages of health care personnel and infrastructure deficiencies, and that it is becoming more and more evident that the private health sector should contribute more towards addressing the HIV/AIDS problem.

Connelly and Rosen (2005) are of the opinion that the implementation of HIV/AIDS programmes by employers could contribute significantly to addressing and managing the negative impacts of HIV / AIDS in the workplace. The results of this particular study indicated that larger firms tend to implement HIV / AIDS programmes much faster than small and medium-sized firms, and that many HR departments at firms were not convinced of the potential effectiveness of HIV / AIDS programmes, and that especially small and medium sized firms lacked the urgency to invest scarce resources in order to address the potential negative impacts of HIV / AIDS.

Vass (2005) conducted a study of the relationship between labour market dynamics and HIV/ AIDS prevalence in South Africa. The study indicated that the rate of labour force growth would decline when the HIV/AIDS prevalence rate increased. This would most certainly result in a smaller 
labour force when compared to a no-HIV / AIDS scenario. This particular study also concluded that the HIV / AIDS prevalence ratios in the manufacturing and mining sectors of South Africa were relatively high (between $20 \%$ and $25 \%$ ).

\section{The link between HIV/AIDS prevalence rates and skill levels, productivity, managerial efficiency, operating costs and profitability indicators}

Studies conducted by Ouattek (2000), the Bureau for Economic Research (2001) and Shisana and Simbayi (2002) explored the relationship between HIV/AIDS prevalence rates and skill levels. It was concluded in all three studies that the HIV/ AIDS prevalence rates were higher among unskilled and semiskilled labour when compared to highly skilled labour (semiand unskilled between $26 \%$ and $33 \%$, skilled between $21 \%$ and $24 \%$, and highly skilled between $11 \%$ and $17 \%$ ). These results confirm the skills gradient (negative relationship between skills levels and HIV / AIDS prevalence rates). Studies conducted by ABT Associates Inc. (2000) and Acott (2000) actually confirmed a constant HIV / AIDS risk profile across skill levels. Vass (2005) indicated higher rates of HIV/AIDS prevalence among nonpermanent workers (who tend to be relatively low skilled and low paid) and that firms are increasingly resorting to employing non-permanent workers with reduced or no benefits in order to circumvent the impact of HIV / AIDS.

Studies done by Fraser, Grant, Mwanza and Naidoo (2002) also indicated that HIV/AIDS impacts on all skill levels in organisations. More importantly, these particular studies highlighted the positive link between skill levels and firm efficiency, suggesting that high levels of HIV/AIDS incidence would impact negatively on firm efficiency. An article by Lisk (2002) further indicated that firm profitability would ultimately be impacted negatively.

Productivity SA (2008) indicated that labour productivity is closely linked to the level of efficiency of a firm and that any negative productivity shock will impact negatively on firm efficiency. Their report further indicated that labour productivity is viewed as a measure of the efficiency with which labour input is utilised. In a report released by the Department of Labour (2007) it was emphasised that firms must initiate the measurement of labour productivity at some point. A systematic and analytical approach towards the measurement of productivity is needed for a focused level of improvement in labour productivity (or to identify exogenous shock impacts on labour productivity). The Bureau for Economic Research (2004), Deloitte and Touche (2001) and Kew (2002) concluded from their research findings that high HIV / AIDS prevalence rates have a strong negative impact on productivity levels, and ultimately on operating costs.

Limited research has been conducted on the actual technical measurement of the impact of HIV / AIDS on firm efficiency and firm competitiveness (see, e.g., Ellis \& Terwin, 2003; Connelly \& Rosen, 2005). This state of affairs necessitates sound technical measurement of the impact of HIV / AIDS on firm efficiency and firm competitiveness.

In conclusion, it is clear from the above discussion that:

- the HIV/AIDS prevalence rates in the manufacturing sector are relatively high

- the implementation or non-implementation of HIV/AIDS programmes by businesses will have an effect on the quality and cost of the labour input

- HIV/AIDS impacts on all skill levels, and

- there is a definite negative relationship between HIV/AIDS and labour productivity, operating costs and profitability indicators. These findings were incorporated into the research approach and method.

\section{RESEARCH DESIGN \\ Research approach}

The research design comprises two distinct sections. In the first section the four hypotheses were tested and statistically validated by means of the statistical package SPSS for Windows Version 11. In the second section, the extent of the negative impact of HIV/AIDS on firm efficiency and firm competitiveness was determined by means of estimated econometric log-linear power functions.

\section{Research participants}

The methodology adopted in the compilation of the survey was aimed at extracting from the market the extent of the impact of HIV / AIDS on firm efficiency and firm competitiveness. Before designing the survey, a thorough literature study and a great deal of interviews to obtain information and market analysis were done in order to target the correct questions at the respondents. These interviews included many role players in the field, namely HR managers, general managers, operations managers, and regional and sales managers. It was ultimately decided that the measurement of firm efficiency would encompass all aspects pertaining to skill levels, labour productivity, labour costs and production costs, and the measurement of firm competitiveness would encompass all aspects pertaining to sales, prices and profit levels.

The aim of the survey was to reach a respondent base and generate a uniform distribution of usable, answered surveys from across the Gauteng Province. The manufacturer category was divided into sample areas. A list of all manufacturing companies in Gauteng, with their contact details, was obtained from the Manufacturing, Engineering and Related Services SETA (hereafter referred to as MERSET). It was also the aim of the survey to make sure that an acceptable spread of firms across the different sectors of the manufacturing industry was included in the survey. These sectors included basic iron and steel, basic chemicals, plastic products, leather products, wood products, paper products, machinery and equipment, motor vehicles, parts and accessories, and communication equipment.

\section{Research procedure}

A questionnaire (Appendix A) was developed to capture the required data. The questionnaire was designed for simplicity of response in order to capture the greatest level of accuracy in the shortest possible time. The answers were divided into both interval ranges and point estimators. This greatly simplified the interview process and reduced subjective interpretation to a bare minimum. The questionnaire focused independently on each of the dimensions that would determine the extent of the impact of HIV/AIDS on the efficiency and competitiveness of the respondent firms. Each dimension was laid out in order to create a degree of continuity from question to question. The questionnaire contained ten questions that were divided into two different dimensions (a background information section and an HIV/AIDS perception section, covering aspects such as skill levels, work performance, absenteeism, workload, quality of output, work unit and overall productivity, service delivery and labour costs). The questions were based on the extensive literature study and interviews that were conducted on the medical aspects of HIV / AIDS and on the efficiency parameters. The validity of the questionnaire items and the sample size were tested and confirmed by the statistical package. The sample size based on this validation was 198 firms.

\section{Measuring instruments}

The survey was further designed to facilitate the conversion of responses into data points in order to transfer them easily into a database and then interpret them with the assistance of SPSS for Windows. Version 11. Regarding the SPSS package, the data results were tested by employing the Kaiser-Meyer-Olkin measure of sampling adequacy and establishing a covariance matrix in which a reliability analysis could be performed. 
TABLE 1

Statistical results of Section $A$ of the survey questionnaire

\begin{tabular}{lrrr}
\hline NUMBER OF EMPLOYEES & $\begin{array}{r}\text { HIVIAIDS POLICY IN PLACE } \\
\text { TIMELINE OF HIVIAIDS POLICY } \\
\text { (YEARS) }\end{array}$ & $\begin{array}{r}\text { KNOWLEDGE OF HIV STATUS OF } \\
\text { EMPLOYEES }\end{array}$ & $\begin{array}{r}\text { \% HIV POSITIVE EMPLOYEES } \\
\text { Y-20 (3.1\%) }\end{array}$ \\
$21-40(6.7 \%)$ & Yes (81.5\%) & $0-1(10.8 \%)$ & $0-10(50.8 \%)$ \\
$41-60(8.8 \%)$ & & $1-2(31.6 \%)$ & No $(38.5 \%)$ \\
$61-80(14.4 \%)$ & $3-5(38.6 \%)$ & $21-30(14.8 \%)$ \\
$81-100(7.7 \%)$ & & $6-10(16.5)$ & $31-40(9 \%)$ \\
$41-50(2 \%)$
\end{tabular}

More than $100(59.3 \%)$

Source: Survey questionnaire results

In order to quantify the magnitude of the impact of HIV/ AIDS on firm efficiency and firm competitiveness, econometric log-linear power functions were specified and estimated. A main advantage of an estimated log-linear power function is that the impact of the different efficiency and competitiveness components on firm efficiency and firm competitiveness can be deduced directly from the estimated parameter results. Three power functions were specified and estimated.

$\mathrm{U}_{\mathrm{fe}}=\mathrm{a}\left(\mathrm{WP}^{\mathrm{b} 1}\right)\left(\mathrm{AS}^{\mathrm{b} 2}\right)\left(\mathrm{WL}^{\mathrm{b} 3}\right)\left(\mathrm{QO}^{\mathrm{b} 4}\right)\left(\mathrm{AF}^{\mathrm{b} 5}\right)$

$$
\left(\mathrm{OP}^{\mathrm{b} 6}\right)\left(\mathrm{WUP}^{\mathrm{b} 7}\right)\left(\mathrm{OL}^{\mathrm{b} 8}\right)\left(\mathrm{SD}^{\mathrm{b} 9}\right)\left(\mathrm{CS}^{\mathrm{b} 10}\right)
$$

Eqn 1

(where $\mathrm{U}_{\mathrm{fe}}=$ productivity component of firm efficiency; $\mathrm{WP}^{\mathrm{b} 1}=$ work performance; $\mathrm{AS}^{\mathrm{b} 2}=$ absenteeism due to sick leave; $\mathrm{WL}^{\mathrm{b} 3}$ = workload; $\mathrm{QO}^{\mathrm{b} 4}=$ quality of output; $\mathrm{AF}^{\mathrm{b} 5}=$ absenteeism due to sick leave; $\mathrm{OP}^{\mathrm{b} 6}=$ overall productivity; $\mathrm{WUP}^{\mathrm{b} 7}=$ work unit productivity; $\mathrm{OL}^{\mathrm{b} 8}=$ output level of HIV-positive employees; $\mathrm{SD}^{\mathrm{b} 9}=$ service delivery; and $\mathrm{CS}^{\mathrm{b} 10}=$ customer satisfaction).

$\mathrm{U}_{\mathrm{fco}}=\mathrm{a}\left(\mathrm{OLC}^{\mathrm{c}}\right)\left(\mathrm{ROI}^{\mathrm{c} 2}\right)\left(\mathrm{ST}^{\mathrm{c} 3}\right)\left(\mathrm{CR}^{\mathrm{c} 4}\right)\left(\mathrm{PTC}^{\mathrm{c} 5}\right)\left(\mathrm{IT}^{\mathrm{c} 6}\right)\left(\mathrm{PC}^{\mathrm{c}}\right) \quad$ Eqn 2

(where $\mathrm{U}_{\mathrm{fco}}=$ cost component of firm efficiency; $\mathrm{OLC}^{\mathrm{c} 1}$ = overall labour costs; $\mathrm{ROI}^{2}{ }^{2}=$ return on investment; $\mathrm{ST}^{\mathrm{c} 3}=$ staff turnover; $\mathrm{CR}^{44}=$ cost of recruitment; $\mathrm{PTC}^{\mathrm{c}}=$ pre-employment training cost; $\mathrm{IT}^{\mathrm{c}}=$ in-service training cost; and $\mathrm{PC}^{\mathrm{c} 7}=$ production costs).

$\mathrm{U}_{\mathrm{fc}}=\mathrm{a}\left(\mathrm{PR}^{\mathrm{d} 1}\right)\left(\mathrm{PI}^{\mathrm{d} 2}\right)\left(\mathrm{S}^{\mathrm{d} 3}\right)$

Eqn 3

(where $\mathrm{U}_{\mathrm{fc}}=$ firm competitiveness; $\mathrm{PR}^{\mathrm{d} 1}=$ profit; $\mathrm{PI}^{\mathrm{d} 2}$ = prices; and $S^{\mathrm{d} 3}=$ sales).

In order to estimate the parameters of the three equations they were first transformed into double log equations (which are linear in the logarithms), and then these regressions were run on the logarithm of the variable.

$$
\begin{array}{rlrl}
\operatorname{LnU}_{\mathrm{fe}}= & \text { Lna+b1LnWP+b2LnAS+b3LnWL+b4LnQO+b5 } & \\
& \text { LnAF+b6LnOP+b7LnWUP+b8LnOL+b9LnSD } & \\
& +\mathrm{b} 10 \mathrm{LnCS} & & \text { Eqn } 4 \\
\mathrm{LnU}_{\mathrm{fco}}= & \text { Lna+c1LnOLC+c2LnROI+c3LnST+c4LnCR } & \\
& +\mathrm{c} 5 \mathrm{LnPTC}+\mathrm{c} 6 \mathrm{LnIT}+\mathrm{c} 7 \mathrm{LnPC} & \\
\operatorname{LnU}_{\mathrm{fc}}= & \text { Lna }+\mathrm{d} 1 \mathrm{LnPR}+\mathrm{d} 2 \mathrm{LnPI}+\mathrm{d} 3 \mathrm{LnS} & \text { Eqn } 5 \\
& \text { Eqn } 6
\end{array}
$$

Three log-linear regression analyses were performed, on the HIV / AIDS productivity component of firm efficiency; the HIV / AIDS cost component of firm efficiency; and the HIV/AIDS impact on firm competitiveness.

\section{RESULTS}

\section{Hypotheses testing}

The response rate was very high. Of the sample size of 198 questionnaires, 196 questionnaires were ultimately processed.

The existence of an HIV/AIDS programme

The first hypothesis is considered in this section. All the statistical

\begin{tabular}{|c|c|c|c|}
\hline SYMMETRIC MEASURES & & VALUE & APPROX. SIG \\
\hline \multicolumn{4}{|l|}{ Nominal by nominal } \\
\hline Phi & & 0.67 & c \\
\hline Cramer's V & & 0.67 & $c$ \\
\hline N OF VALID CASES & & 194 & \\
\hline \multicolumn{4}{|c|}{$\begin{array}{l}\text { aNot assuming the null hypothesis } \\
\text { bUsing the asymptotic standard error assuming the null hypothesis } \\
\text { Source: SPSS results }\end{array}$} \\
\hline \multicolumn{4}{|c|}{$\begin{array}{c}\text { TABLE } 4 \\
\text { Chi-square tests for duration of an HIVIAIDS policy }\end{array}$} \\
\hline CHI-SQUARE TESTS & VALUE & DF & ASYMP. SIG. (2-sided) \\
\hline Pearson's chi-square & $5.767^{\mathrm{a}}$ & 4 & 0.22 \\
\hline Likelihood ratio & 7.381 & 4 & 0.12 \\
\hline Linear-by-linear association & 4 & 1 & 0.05 \\
\hline N OF VALID CASES & 154 & & \\
\hline
\end{tabular}

TABLE 2

Chi-square test results for the existence of an HIVIAIDS policy

\begin{tabular}{lrrr}
\hline CHI-SQUARE TEST & VALUE & DF & ASYMP. SIG. (2-SIDED) \\
\hline Pearson's chi-square & $88.103^{\mathrm{a}}$ & 2 & 0.000 \\
Likelihood ratio & 77.589 & 2 & 0.000 \\
Linear-by-linear association & 78.565 & 1 & 0.000 \\
\hline N OF VALID CASES & $\mathbf{1 9 4}$ & & \\
\hline
\end{tabular}

a 0 cells $(0.0 \%)$ have expected count less than 5 . The minimum expected count is 6.68 . Source: SPSS results

TABLE 3

Symmetric measures of the existence of an HIVIAIDS policy

a3 cells (33.3\%) have expected count less than 5 . The minimum expected count is 1.75 . Source: SPSS results

TABLE 5

Chi-square tests on the knowledge of HIVIAIDS status of staff

\begin{tabular}{lrrr}
\hline CHI-SQUARE TESTS & VALUE & DF & ASYMP. SIG. (2-sided) \\
\hline Pearson's chi-square & $30.660^{\mathrm{a}}$ & 2 & 0.000 \\
Likelihood ratio & 30.9 & 2 & 0.000 \\
Linear-by-linear association & 30.36 & 1 & 0.000 \\
\hline N OF VALID CASES & 193 & &
\end{tabular}

${ }^{a} 0$ cells $(.0 \%)$ have expected count less than 5 . The minimum expected count is 13.99 . Source: SPSS results

results from the background information of the respondents and the HIV / AIDS aspects are listed in Table 1. The SPSS results deal with questions 3,4 and 5 of the questionnaire.

It was interesting to note that the majority of the firms that participated in the survey employed more than 100 employees $(59.3 \%)$, while an absolute minority of the firms employed fewer than 20 employees $(3.1 \%)$ 
TABLE 6

Impact of HIV/AIDS on skills levels (\% of respondents)

\begin{tabular}{|c|c|c|c|c|}
\hline SKILLS LEVEL & NO EXTENT & MODERATE & LARGE & VERY LARGE \\
\hline No formal education & $2.10 \%$ & $48.70 \%$ & $35.40 \%$ & $2.60 \%$ \\
\hline Pre-matric & $9.20 \%$ & $48.70 \%$ & $28.20 \%$ & $1.50 \%$ \\
\hline Matric & $14.90 \%$ & $50 \%$ & $28.40 \%$ & $0.50 \%$ \\
\hline Certificate & $16.50 \%$ & $54.10 \%$ & $24.20 \%$ & $0 \%$ \\
\hline Diploma & $16 \%$ & $57.70 \%$ & $21.10 \%$ & $0 \%$ \\
\hline Degree and higher & $14.40 \%$ & $58.80 \%$ & $24.70 \%$ & $0 \%$ \\
\hline
\end{tabular}

Source: Survey questionnaire

TABLE 7

Impact of HIV/AIDS on productivity levels (\% of respondents)

\begin{tabular}{|c|c|c|c|c|c|}
\hline & NO EXTENT & SMALLER EXTENT & MODERATE EXTENT & LARGE EXTENT & VERY LARGE EXTENT \\
\hline Work performance & $9.20 \%$ & $58.50 \%$ & $28.20 \%$ & $4.10 \%$ & $0 \%$ \\
\hline Absenteeism due to sick leave & $8.20 \%$ & $57.90 \%$ & $29.20 \%$ & $3.60 \%$ & $1 \%$ \\
\hline Workload & $23.60 \%$ & $58.50 \%$ & $15.90 \%$ & $1.50 \%$ & $0.50 \%$ \\
\hline Quality of output & $28.70 \%$ & $60.50 \%$ & $9.70 \%$ & $1 \%$ & $0 \%$ \\
\hline Absenteeism due to funeral attendance & $31.30 \%$ & $52.30 \%$ & $12.80 \%$ & $3.60 \%$ & $0 \%$ \\
\hline Overall productivity & $47.70 \%$ & $39 \%$ & $12.30 \%$ & $1 \%$ & $0 \%$ \\
\hline Work unit productivity & $42.10 \%$ & $43.60 \%$ & $12.80 \%$ & $1.50 \%$ & $0 \%$ \\
\hline Output level of HIV-positive employees & $23.60 \%$ & $54.90 \%$ & $17.40 \%$ & $3.60 \%$ & $0.50 \%$ \\
\hline Service delivery & $50.80 \%$ & $34.90 \%$ & $12.80 \%$ & $1.50 \%$ & $0 \%$ \\
\hline Customer satisfaction & $54.40 \%$ & $35.40 \%$ & $9.20 \%$ & $1 \%$ & $0 \%$ \\
\hline
\end{tabular}

Source: Survey questionnaire

In terms of the status of their HIV / AIDS policy, a total number of 159 firms indicated that they had HIV/AIDS policies in place $(81.5 \%)$, while only $37(18.5 \%)$ respondents indicated that they did not have HIV/AIDS policies in place. Regarding the historical timeline of the HIV / AIDS policy, the majority of the respondents had these policies in place for a period of less than five years $(81 \%)$.

A total number of 120 (61.5\%) respondents indicated that they knew the HIV / AIDS status of their employees, while 76 (38.5\%) respondents indicated that they had no knowledge concerning the HIV/AIDS status of their employees. The discrepancy between the number of firms that had HIV/AIDS policies in place and the number of respondents who knew the HIV/ AIDS status of their employees (39 respondents) may probably be attributed to anxiety and reluctance among employees to disclose their HIV / AIDS status.

The results relating to the percentage of employees who were HIV positive were interesting. A total number of $50.8 \%$ of the respondents who had knowledge of the HIV / AIDS status of their employees indicated that fewer than $10 \%$ of their employees were HIV positive. A further $22.1 \%$ of the respondents indicated that the HIV infection rate among their employees was between $11 \%$ and $20 \%$. Only $2 \%$ of the respondents indicated an HIV infection rate of more than $40 \%$. These results are contradictory to the high $\mathrm{HIV}$ infection rates recorded by the health authorities. It was also clear from the results that the majority of the respondents $(66.7 \%)$ were serious about making voluntary testing and counselling available for their employees and about encouraging them to know and disclose their HIV / AIDS status.

In terms of the SPSS results, three important aspects were considered, namely:

- whether the organisation had an HIV/AIDS policy

- the duration of the HIV / AIDS policy and

- knowledge of the HIV / AIDS status of the staff.

Regarding the existence of an HIV/AIDS policy, the Pearson's chi-square of 0.000 clearly indicated a high correlation (see Table 2).
Symmetric measures in terms of the Phi (0.000) and Cramer's (0.000) tests confirmed the clear acceptance of the hypothesis in this regard (see Table 3).

Regarding the duration of an HIV/AIDS policy, the crosstabulation clearly indicated a positive relationship between the size of the firm (measured by the number of employees) and the duration of an HIV / AIDS policy: the greater the size of the firm, the longer the duration of the HIV/AIDS policy.

The chi-square tests indicated no statistical significance (Pearson's chi-square of 0.217) in terms of the duration of an HIV / AIDS policy (see Table 4). This was due to the fact that the expected count was less than five for organisations with fewer than 100 employees.

The chi-square tests indicated statistical significance (Pearson's chi-square of 0.000) in terms of knowledge of the HIV/AIDS status of employees (see Table 5). The cross-tabulation also indicated a high correlation between the size of the organisation and knowledge of the HIV/AIDS status of the employees.

It is concluded that firms in the manufacturing sector of the economy in general have HIV/AIDS programmes in place, irrespective of their size.

HIV/AIDS impact on skill levels and labour productivity components

The second hypothesis is considered in this section. The respondents' perceptions regarding the impact of HIV/AIDS on firm efficiency and firm competitiveness are of particular importance to this article. The first question in this section related to the extent to which HIV / AIDS impacted on skill levels in the organisation. Six (low to higher) education and training levels were indicated as a proxy for skill levels. The statistical results of this particular aspect are listed in Table 6.

Table 6 indicates that all skill levels were equally affected by HIV/AIDS (from a moderate to a large extent). This finding is in line with comments in the literature that HIV/AIDS impacts 
TABLE 8

Reliability statistics (on the combination of questions 7-9)

\begin{tabular}{lccc}
\hline & RELIABILITY STATISTICS & \\
\hline CRONBACH'S ALPHA & CRONBACH'S ALPHA BASED ON STANDARDISED ITEMS & N OF ITEMS & 12 \\
\hline 0.889 & 0.890 & \\
\hline
\end{tabular}

TABLE 9

Tests of normality (questions 7-9)

\begin{tabular}{|c|c|c|c|c|c|c|c|}
\hline \multicolumn{8}{|c|}{ TESTS OF NORMALITY } \\
\hline \multirow{2}{*}{ PERCENTAGE OF EMPLOYEES WHO ARE HIV POSITIVE } & & \multicolumn{3}{|c|}{ KOLMOGOROV-SMIRNOV } & \multicolumn{3}{|c|}{ SHAPIRO-WILK } \\
\hline & & STATISTIC & DF & SIG. & STATISTIC & DF & SIG. \\
\hline . & Q8_9 & 0.250 & 73 & 0.000 & 0.793 & 73 & 0.000 \\
\hline $0-10 \%$ & Q8_9 & 0.179 & 62 & 0.000 & 0.891 & 62 & 0.000 \\
\hline $11-20 \%$ & Q8_9 & 0.142 & 27 & 0.173 & 0.941 & 27 & 0.125 \\
\hline$>20 \%$ & Q8_9 & 0.141 & 33 & 0.093 & 0.949 & 33 & 0.123 \\
\hline
\end{tabular}

ailliefors significance correction

Source: SPSS results

TABLE 10

ANOVA results (questions 7-9)

\begin{tabular}{|c|c|c|c|c|c|}
\hline & \multicolumn{5}{|c|}{ ANOVA Q 7-9 } \\
\hline & SUM OF SQUARES & DF & MEAN SQUARE & $\mathbf{F}$ & SIG \\
\hline Between groups & 6.062 & 2 & 3.031 & 15.111 & 0.000 \\
\hline Within groups & 23.867 & 119 & 0.201 & & \\
\hline TOTAL & 29.929 & 121 & & & \\
\hline
\end{tabular}

on all the different categories of educated and non-educated employees.

The impact of HIV/AIDS on important components of labour productivity was measured in the survey. The results obtained from the survey questionnaire with regard to these components are listed in Table 7.

It can be deduced from Table 7 that firms are already experiencing small to moderate negative impacts of HIV/ AIDS on productivity levels. It is important to link the results in this table to the results contained in Table 1. The HIV / AIDS incidence rate for the majority of firms was relatively low $(72 \%$ of the respondents had a known HIV/AIDS incidence rate of $20 \%$ and less).

Questions 7, 8 and 9 are closely linked and were combined for the purposes of the SPSS analysis. The Cronbach's alpha of 0.889 confirms the reliability of combining the three questions.

An item-total statistical matrix (see Appendix B) was compiled in order to determine the correlation between HIV / AIDS and the various components of productivity. All the correlations were positive and had a relatively high degree of correlation, except those with regard to the transfer of employees to lighter duties $(0.249)$ and the increase in the size of the workforce to cater for employees who become ill because of HIV / AIDS (0.250).

The percentages of employees with HIV/AIDS were divided into four intervals, namely total number interval, a $0 \%-10 \%$ interval, an $11 \%-20 \%$ interval and a greater than $20 \%$ interval (SPSS interval descriptive statistics are listed in Appendix C).

The statistics were parametric and it was expected that the underlying distributions would be normal. The KolmogorovSmirnov and the Shapiro-Wilk tests of normality were used to test for normality. The Kolmogorov-Smirnov and Shapiro-Wilk results clearly rejected normal distributions for the $11 \%-20 \%$ and the greater than $20 \%$ intervals (Table 9).
It was then decided to collapse the interval and proceed with an ANOVA analysis. The ANOVA statistic of 0.000 indicated a high level of correlation between employees with HIV / AIDS and the impact on the different productivity components (Table 10).

The Brown-Forsythe significance statistic of 0.000 confirmed the robustness of the ANOVA result (Table 11).

The Kruskal-Wallis test was conducted in order to either reject or confirm the parametric results. The chi-square asymmetric significance of 0.000 was a further confirmation of the strong negative correlation between the number of HIV/AIDS employees and the different components of productivity (Table 12).

It therefore can be accepted that HIV/AIDS has a definite negative relationship with the different components of labour productivity.

The impact of HIV / AIDS on labour and production costs

The third hypothesis is considered in this section. Table 13 lists the responses regarding the impact of HIV/AIDS on labour costs, training costs, staff turnover, cost of recruitment, pre-employment training costs, in-service training costs and production costs.

It was clear from the results that a majority of the firms were experiencing cost pressures due to the impact of HIV/AIDS. A clearer picture emerged when the categories 'smaller extent', 'moderate extent' and 'very large extent' were aggregated. The average number of firms that were already experiencing cost pressures in all the categories listed in Table 13 was approximately $85 \%$.

The hypothesis dealt with question 10 of the questionnaire. The percentages of employees with HIV/AIDS were again divided into four intervals, namely total number interval, a $0 \%-10 \%$ interval, an $11 \%-20 \%$ interval and a greater than $20 \%$ interval. 
TABLE 11

Robust tests of equality of means (questions $7-9$ )

\begin{tabular}{lrrrr}
\hline & \multicolumn{4}{c}{ ROBUST TESTS OF EQUALITY OF MEANS Q7-9 } \\
\cline { 2 - 5 } & STATISTIC $^{a}$ & DF1 & DF2 & SIG. \\
\hline Brown-Forsythe & 13.37 & 2 & 79.48 & 0.000 \\
\hline
\end{tabular}

asymptotically $F$ distributed

Source: SPSS results

TABLE 12

Test statistics of the Kruskal-Wallis test (questions 7-9)

\begin{tabular}{lcr}
\hline & \multicolumn{2}{c}{ TEST STATISTICS $^{\text {a.b }}$} \\
\cline { 2 - 3 } & \multicolumn{2}{c}{ IMPACT OF HIVIAIDS ON } \\
& WORK PERFORMANCE ETC. & Q7-9 \\
\hline Chi-square & 22.77 & 22.59 \\
df & 2 & 2 \\
Asymp. sig. & 0.000 & 0.000 \\
\hline a'Kruskal-Wallis test & \\
brouping variable: percentage of employees who are HIV positive & \\
Source: SPSS results &
\end{tabular}

The SPSS interval descriptive statistics are listed in Appendix D.

The statistics were parametric and it was expected that the underlying distributions would be normal. Both the Kolmogorov-Smirnov and Shapiro-Wilk results clearly rejected normal distributions for the $11 \%-20 \%$ and the greater than $20 \%$ intervals (Table 14)

It was again decided to collapse the interval and proceed with the ANOVA analysis. The ANOVA statistic of 0.000 indicated a high level of correlation between employees with HIV / AIDS and the impact on labour and production costs (Table 15).

The Brown-Forsythe significance statistic of 0.000 confirmed the robustness of the ANOVA result (Table 16).

The chi-square asymmetric significance of .000 was a further confirmation of the negative correlation between the number of employees with HIV/AIDS and production and labour costs (Table 17)

TABLE 13

Impact of HIVIAIDS on labour costs, training costs, staff turnover, cost of recruitment, pre-employment training costs, in-service training costs and production costs (\% of respondents)

\begin{tabular}{|c|c|c|c|c|c|}
\hline & NO EXTENT & SMALLER EXTENT & MODERATE EXTENT & LARGE EXTENT & VERY LARGE EXTENT \\
\hline Labour costs & $2.60 \%$ & $55.90 \%$ & $27.20 \%$ & $12.30 \%$ & $2.10 \%$ \\
\hline HIV-related costs & $7.70 \%$ & $49.70 \%$ & $26.70 \%$ & $12.80 \%$ & $3.10 \%$ \\
\hline Training costs & $30.80 \%$ & $31.80 \%$ & $26.70 \%$ & $10.30 \%$ & $0.50 \%$ \\
\hline Staff turnover & $8.20 \%$ & $48.70 \%$ & $25.60 \%$ & $14.90 \%$ & $2.60 \%$ \\
\hline Cost of recruitment & $29.20 \%$ & $31.80 \%$ & $24.10 \%$ & $17.40 \%$ & $4.10 \%$ \\
\hline Pre-employment training costs & $6.20 \%$ & $48.70 \%$ & $25.10 \%$ & $16.90 \%$ & $3.10 \%$ \\
\hline In-service training costs & $8.70 \%$ & $22.10 \%$ & $51.80 \%$ & $14.40 \%$ & $3.10 \%$ \\
\hline Production costs & $26.20 \%$ & $28.20 \%$ & $25.60 \%$ & $14.40 \%$ & $5.60 \%$ \\
\hline
\end{tabular}

TABLE 14

Tests of normality (question 10)

\begin{tabular}{|c|c|c|c|c|c|c|c|}
\hline \multicolumn{8}{|c|}{ TESTS OF NORMALITY } \\
\hline PERCENTAGE OF EMPLOYEES WHO & & \multicolumn{3}{|c|}{ KOLMOGOROV-SMIRNOV } & \multicolumn{3}{|c|}{ SHAPIRO-WILK } \\
\hline ARE HIV POSITIVE & & STATISTIC & DF & SIG. & STATISTIC & DF & SIG. \\
\hline . & Impact on costs & 0.31 & 73 & 0.000 & 0.747 & 73 & 0.000 \\
\hline $0-10 \%$ & Impact on costs & 0.19 & 62 & 0.000 & 0.914 & 62 & 0.000 \\
\hline $11-20 \%$ & Impact on costs & 0.14 & 27 & 0.190 & 0.932 & 27 & 0.076 \\
\hline$>20 \%$ & Impact on costs & 0.18 & 33 & 0.009 & 0.917 & 33 & 0.015 \\
\hline
\end{tabular}

Lilliefors significance correction

Source: SPSS results

TABLE 15

ANOVA results (question 10)

\begin{tabular}{lrrrrr}
\hline & & \multicolumn{3}{c}{ ANOVA: IMPACT ON COSTS } \\
\cline { 2 - 6 } & SUM OF SQUARES & DF & MEAN SQUARE & F & \\
\hline Between groups & 15.327 & 2 & 7.664 & 12.957 \\
Within groups & 70.382 & 119 & 0.591 & \\
\hline TOTAL & $\mathbf{8 5 . 7 0 9}$ & $\mathbf{1 2 1}$ & & & \\
\hline
\end{tabular}

Source: SPSS results

TABLE 16

TABLE 16
Robust tests of equality of means

\begin{tabular}{lrrr}
\hline \multicolumn{4}{c}{ ROBUST TESTS OF EQUALITY OF MEANS: IMPACT ON COSTS } \\
\begin{tabular}{lrrr}
\hline STATISTIC & DF1 & DF2 & SIG. \\
\hline 11.946 & 2 & 82.583 & 0.000 \\
\hline aAsymptotically F distributed & & & \\
Source: SPSS results & & &
\end{tabular}
\end{tabular}

TABLE 17

Test statistics of the Kruskal-Wallis test (question 10)

\begin{tabular}{lr}
\hline \multicolumn{2}{c}{ TEST STATISTICS ${ }^{\text {a.b }}$} \\
\hline Chi-Square & IMPACT ON COSTS \\
df & 18.95 \\
Asymp. sig. & 0 \\
\hline aKruskal-Wallis test & 0 \\
bGrouping variable: Percentage of employees who are HIV positive & \\
Source: SPSS results &
\end{tabular}


TABLE 18

The negative impact of HIVIAIDS on profit margins, prices and sales (\% of respondents)

\begin{tabular}{lrrrr}
\hline & NO EXTENT & $\begin{array}{r}\text { SMALLER } \\
\text { EXTENT }\end{array}$ & $\begin{array}{r}\text { MODERATE } \\
\text { EXTENT }\end{array}$ & $\begin{array}{r}\text { LARGE } \\
\text { EXTENT }\end{array}$ \\
\hline Profit margins & $62.20 \%$ & $31.10 \%$ & $6.20 \%$ & $0.50 \%$ \\
Prices & $66.30 \%$ & $29.50 \%$ & $3.60 \%$ & $0.50 \%$ \\
Sales & $64.60 \%$ & $32 \%$ & $2.80 \%$ & $0.60 \%$ \\
\hline
\end{tabular}

Source: Survey questionnaire

It can be accepted that HIV/AIDS has a negative impact on labour and production costs.

The impact of HIV/AIDS on the level of firm competitiveness (profit margins, prices and sales)

The fourth hypothesis is considered in this section. Table 18 lists the responses with regard to the impact on profit margins, prices and sales.

The results listed in Table 18 are remarkable. Despite the negative impact of HIV/AIDS on labour and production costs, it is interesting to note that the majority of the respondents indicated that it had no impact or only a small impact on profit margins, price policy and sales figures. A plausible explanation for this state of affairs is that the firms in the sample group operate in less competitive industries (such as oligopoly structures) and that cost pressures are simply passed on to the final customers.

The hypothesis dealt with question 11 of the questionnaire. The percentage of employees with HIV/AIDS were again divided into four intervals, namely total number interval, a $0 \%-10 \%$ interval, an $11 \%-20 \%$ interval and a greater than $20 \%$ interval. The SPSS interval descriptive statistics are listed in Appendix E.

TheKolmogorov-Smirnov and theShapiro-Wilk tests of normality were again used to test for normality. The Kolmogorov-Smirnov and Shapiro-Wilk results clearly rejected normal distributions for the greater than $20 \%$ interval (Table 19).

It was again decided to collapse the interval and proceed with the ANOVA analysis. The ANOVA statistic of 0.006 indicated a high level of correlation between employees with HIV / AIDS and the impact on profit, prices and sales (Table 20).

The Brown-Forsythe significance statistic of 0.010 confirmed the robustness of the ANOVA result (Table 21).

It was also decided to test for the homogeneity of the variances. The Levene statistic of 0.000 confirmed the high degree of homogeneity of the variances (Table 22).

TABLE 19

Tests of normality (question 11)

\begin{tabular}{|c|c|c|c|c|c|c|c|}
\hline \multicolumn{8}{|c|}{ TESTS OF NORMALITY } \\
\hline \multirow{2}{*}{$\begin{array}{l}\text { PERCENTAGE OF EMPLOYEES WHO } \\
\text { ARE HIV POSITIVE }\end{array}$} & & \multicolumn{3}{|c|}{ KOLMOGOROV-SMIRNOV } & \multicolumn{3}{|c|}{ SHAPIRO-WILK } \\
\hline & & STATISTIC & DF & SIG. & STATISTIC & DF & SIG. \\
\hline$\cdot$ & Impact on profit, prices and sales & 0.450 & 72 & 0.000 & 0.570 & 72 & 0.000 \\
\hline $0-10 \%$ & Impact on profit, prices and sales & 0.310 & 62 & 0.000 & 0.736 & 62 & 0.000 \\
\hline $11-20 \%$ & Impact on profit, prices and sales & 0.269 & 27 & 0.190 & 0.742 & 27 & 0.000 \\
\hline$>20 \%$ & Impact on profit, prices and sales & 0.189 & 32 & 0.009 & 0.861 & 32 & 0.001 \\
\hline
\end{tabular}

aLilliefors significance correction

Source: SPSS results

TABLE 20

ANOVA results (question 11)

\begin{tabular}{lrrrrr}
\hline & \multicolumn{4}{c}{ ANOVA: IMPACT ON PROFIT, PRICES AND SALES } & \\
\hline & SUM OF SQUARES & DF & MEAN SQUARE & F & \\
\hline Between groups & 3.66 & 2 & 1.828 & \\
Within groups & 39.909 & 118 & 0.338 & \\
\hline TOTAL & $\mathbf{4 3 . 5 6 5}$ & $\mathbf{1 2 0}$ & & \\
\hline
\end{tabular}

Source: SPSS results

TABLE 21

Robust tests of equality of means (question 11)

\begin{tabular}{lrrrrr}
\hline & \multicolumn{4}{c}{$\begin{array}{c}\text { ROBUST TESTS OF EQUALITY OF MEANS Q11: } \\
\text { IMPACT ON PROFIT, PRICES AND SALES }\end{array}$} \\
\cline { 2 - 6 } & STATISTIC $^{\mathrm{a}}$ & DF1 & DF2 & SIG. \\
\hline Brown-Forsythe & 4.888 & 2 & 66.504 & 0.010 \\
\hline
\end{tabular}

asymptotically $\mathrm{F}$ distributed

TABLE 22

Test of homogeneity of variances (question 11)
TABLE 23

Test statistics of the Kruskal-Wallis test

\begin{tabular}{lr}
\hline \multicolumn{2}{c}{ TEST STATISTICS ${ }^{\mathrm{a}, \mathrm{b}}$} \\
\hline \multicolumn{2}{c}{ IMPACT ON PROFIT, PRICES AND SALES } \\
\hline Chi-square & 6.637 \\
df & 2 \\
Asymp. Sig. & 0.036 \\
\hline
\end{tabular}

aKruskal-Wallis test

${ }^{\mathrm{b}}$ Grouping variable: percentage of employees who are HIV positive

Source: SPSS results

\begin{tabular}{|c|c|c|c|}
\hline \multicolumn{4}{|c|}{$\begin{array}{l}\text { TEST OF HOMOGENEITY OF VARIANCES: IMPACT ON PROFIT, } \\
\text { PRICES AND SALES }\end{array}$} \\
\hline LEVENE STATISTIC & DF1 & DF2 & SIG. \\
\hline 8.76 & 2 & 118 & 0.000 \\
\hline
\end{tabular}


TABLE 24

Regression results for $\mathrm{U}$

\begin{tabular}{lrr}
\hline PARAMETER & ESTIMATED COEFFICIENTS & t-STAT \\
\hline b1 & -2.26 & 4.15 \\
b2 & -4.13 & 6.12 \\
b3 & -3.11 & 4.03 \\
b4 & -0.85 & 3.88 \\
b5 & -0.67 & 2.95 \\
b6 & -6.15 & 5.10 \\
b7 & -8.05 & 4.73 \\
b8 & -1.98 & 2.19 \\
b9 & -1.01 & 2.44 \\
b10 & -0.62 & 2.52 \\
\hline
\end{tabular}

* Dependent variable: $\bigcup_{\text {fe }}$

** DW-stat: 8.25

${ }^{* * *} R^{2}: 0.92$

****All t-values are statistically significant

*****No autocorrelation detected

TABLE 25

Regression results for $\bigcup_{\text {fco }}$

\begin{tabular}{lrr}
\hline PARAMETER & ESTIMATED COEFFICIENTS & t-STAT \\
\hline c1 & -9.11 & 3.12 \\
c2 & -7.23 & 4.91 \\
c3 & -8.10 & 3.77 \\
c4 & -10.22 & 4.15 \\
c5 & -4.72 & 2.81 \\
c6 & -2.92 & 4.55 \\
c7 & -6.78 & 3.64 \\
\hline
\end{tabular}

* Dependent variable: $\bigcup_{\text {fco }}$

** DW-stat: 9.12

${ }^{* * *} R^{2}: 0.86$

${ }^{\star * \star *}$ All t-values are statistically significant

***** No autocorrelation detected

TABLE 26

Regression results for $\mathrm{U}$

\begin{tabular}{lrr}
\hline PARAMETER & ESTIMATED COEFFICIENTS & t-STAT \\
\hline $\mathrm{d} 1$ & -1.04 & 3.41 \\
$\mathrm{~d} 2$ & -0.67 & 2.79 \\
$\mathrm{~d} 3$ & -0.15 & 4.01 \\
\hline * Dependent variable: $\mathrm{U}_{\mathrm{fc}}$ & & \\
${ }^{* *}$ DW-stat: 6.11 & & \\
${ }^{* * *} \mathrm{R}^{2}: 0.84$ & & \\
${ }^{* * * * A l l}$ t-values are statistically significant & & \\
${ }^{* * * * *}$ No autocorrelation detected & &
\end{tabular}

The Kruskal-Wallis test was again conducted in order to either reject or confirm the parametric results. The chi-square asymmetric significance of 0.036 was a further confirmation of the negative correlation between the number of employees with HIV / AIDS and profits, prices and sales (Table 23).

It can therefore be accepted that HIV/AIDS will impact negatively on profit levels, prices and sales.

\section{The determination of the extent of the impact of HIV/AIDS on firm efficiency and firm competitiveness}

The estimated parameter coefficient results for the three loglinear power functions are listed in Tables 24 to 26 .

The negative signs of the estimated parameter coefficients again confirmed the negative impact of all the different HIV/AIDS productivity-related efficiency components on firm efficiency. The magnitude of most of the negative impacts of the different HIV / AIDS-related productivity components on firm efficiency were very high (given by estimated coefficients greater than 1 ).
The only exceptions were the quality of output, absenteeism due to funeral attendance and customer satisfaction.

The negative signs of all the estimated HIV / AIDS cost-related component coefficients also confirmed the negative relationship between HIV/AIDS prevalence rates and firm efficiency. The absolute values of the estimated cost-related parameter coefficients were very high, thus indicating a very strong negative impact of HIV / AIDS prevalence rates on firm efficiency (all the estimated coefficients had an absolute value greater than 1).

The negative signs of the estimated parameter coefficients are an indication of the negative impact that HIV/AIDS exerts on firm competitiveness. The magnitude of the impact on firm competitiveness is relatively weak, as two of the three categories have estimated coefficients of less than 1 (in absolute terms). This is a further confirmation of the SPSS result (as discussed earlier in the paper) regarding the relationship between HIV/ AIDS prevalence and firm competitiveness. Notwithstanding this particular result it is important to note that the relationship is still a negative one and that the extent of the impact might increase over time.

\section{DISCUSSION}

The results of the research clearly indicate a rising trend in HIV / AIDS incidence rates in the manufacturing sector of the economy. More and more firms are formulating and implementing HIV/ AIDS programmes (smaller to medium-sized firms to a lesser extent). Firms cannot afford not to implement or manage HIV/ AIDS programmes. It has been proven in the research that HIV/ AIDS is starting to exert a serious negative impact on the level of firm efficiency (skills levels, labour productivity, labour costs and production costs), and ultimately on firm competitiveness (sales, prices and profitability). There are two very important aspects to consider. Firstly, HIV/AIDS programmes and the human resource base of firms require a greater level of effective management in order to limit the extent of the negative impacts of HIV/AIDS. Secondly, firms should also develop, implement and utilise more sophisticated firm-based impact models (measurements) that can quickly and effectively track negative HIV / AIDS effects so that corrective measures can be implemented speedily.

It should be borne in mind that this research focused on one specific sector of the South African economy. Further research on the impact of HIV/AIDS on all the different sectors of the economy is necessary in order to determine whether the differences in the labour dynamics of the different sectors play an important role when the negative efficiency and competitive impacts of HIV / AIDS are considered. It will most certainly give decision makers (at firm, industry and national levels) greater insight into the nature and extent of the negative impacts of HIV/AIDS on firm efficiency and firm competitiveness. Further research on the development of sophisticated and sound econometric firm-based HIV/AIDS impact models is of paramount importance.

\section{Conclusion}

The majority of firms in the sample group indicated that they had an HIV / AIDS policy in place, that they had knowledge of the HIV / AIDS status of their employees, and that they had had $\mathrm{HIV} / \mathrm{AIDS}$ programmes in place for a period of longer than five years. A majority of the firms also indicated that the infection rate of their workforce was currently relatively moderate. It was interesting to note that all skills levels were equally affected by HIV / AIDS (albeit from a moderate to large extent) and that the extent of the negative impact of HIV/AIDS is on an upward trend.

The majority of the firms indicated that they were already experiencing cost pressures due to the impact of HIV/AIDS. Efficiency levels were also affected negatively by HIV / AIDS. It was concluded that, despite the negative impact of HIV/AIDS 
on production costs, the majority of firms experienced only a small impact on profit margins, pricing policy and sales figures. The only conclusion (assumption) that could be drawn from this state of affairs is that this particular sample group operated in less competitive industries (oligopoly structures) and that cost pressures (as a result of HIV/AIDS) were passed on to the final consumers.

\section{REFERENCES}

ABT Associates Inc. (2000). Demographic impacts of HIV/AIDS in South Africa. Sandton: ABT Associates Inc

Acott, D. (2000). The impact of AIDS in South Africa: a critique of demographic methods used in the ING Barings report of April 2000, and their implications. Unpublished honours thesis, University of Cape Town, Cape Town, South Africa.

Bureau for Economic Research. (2001). The macro-economic impact of HIV/AIDS in South Africa. Economic Research Note No 10. Stellenbosch: Bureau for Economic Research.

Bureau for Economic Research. (2004). The economic impact of HIV/AIDS on business in South Africa. Stellenbosch: Bureau for Economic Research

Call, S.T., \& Holahan, W.L. (1983). Microeconomics. San Francisco: Wadsworth.

Cleary, S., Boulle, A., Castillo-Riquelme, M., \& McIntyre, D. (2008). The burden of HIV/AIDS in the public healthcare system. South African Journal of Economics, 76(S1), 3-14.

Connelly, P., \& Rosen, S. (2005). Will small and medium enterprises provide HIV/AIDS services to employees? An analysis of market demand. The South African Journal of Economics, 73, 613-625.

Deloitte and Touche. (2002). Evaluation of workplace responses to HIV/AIDS in South Africa - a rapid situation analysis. Johannesburg: Deloitte and Touche Human Capital Corporation.

Department of Labour. (2007). National Skills Development Strategy: Implementation Report 1. Pretoria: Department of Labour.

Ellis, L., \& Terwin, J. (2003). The economic impact of HIV/AIDS on business in South Africa. Stellenbosch: Bureau for Economic Research.

Fraser, F., Grant, W., Mwanza, P., \& Naidoo, V. (2002). The impact of HIV/AIDS on small and medium enterprises in South Africa. South African Journal of Economics 70(7), 1216-1234.

Kew, J. (2002, 12 September). Old Mutual launches staff AIDS plan. Business Day.

Lisk, D. (2002). Labour market implications of HIV/AIDS in SubSaharan Africa (Working Paper 1). Geneva: ILO.

Masuku, S.D. (2005). The importance of human capital in the manufacturing sector of the South African economy. Unpublished master's thesis, University of Johannesburg, Johannesburg, South Africa.

Ouattek, K. (2000). The economic impact of AIDS on South Africa: A dark cloud on the horizon. Johannesburg: ING Barings.

Productivity SA. (2008). A study of the impact of skills development on productivity and competitiveness in South Africa: a synthesis report. Johannesburg: Productivity SA.

Shisana, O., \& Simbayi, L. (2002). South African National HIV Prevalence, Behavioural Risks and Mass Media Household Survey 2002. Cape Town: Human Science Research Council.

Vass, J. (2005). The relationship between labour market dynamics and HIV/AIDS prevalence in South Africa - a literature review. The South African Journal of Economics, 73, 564-577.

\section{APPENDICES \\ APPENDIX A \\ Survey questionnaire}

SECTION A: BACKGROUND INFORMATION

This section of the questionnaire refers to background information. Although we are aware of the sensitivity of the questions in this section, the information will allow us to compare groups of respondents. Once again, we assure you that your response will remain anonymous. Your cooperation is appreciated.

1. Type of industry, mark ONE option only.

\begin{tabular}{|l|l|}
\hline Basic iron \& steel & 1 \\
\hline Basic chemicals & 2 \\
\hline Plastic products & 3 \\
\hline Leather products & 4 \\
\hline Wood products & 5 \\
\hline Paper products & 6 \\
\hline Machinery \& equipment & 7 \\
\hline Motor vehicles, parts \& accessories & 8 \\
\hline TV, radio \& communication equipment & 9 \\
\hline Other, please specify & 10 \\
\hline
\end{tabular}

2. Please indicate the number of employees in your establishment.

\begin{tabular}{|l|l|l|l|l|l|}
\hline $0-20$ & $21-40$ & $41-60$ & $61-80$ & $81-100$ & 101 and more \\
\hline
\end{tabular}

3. Does your organisation have an HIV policy?

\begin{tabular}{|l|l|l|l|}
\hline Yes & No & \\
\hline
\end{tabular}

If your answer to question 3 is NO, please skip question 4 and proceed to question 5 .

4. If your organisation has an HIV policy, how long has the HIVIAIDS policy been in place?

\begin{tabular}{|l|l|}
\hline Less than 1 year & \\
\hline $1-2$ years & \\
\hline $3-5$ years & \\
\hline $6-10$ years & \\
\hline 10 years or more & \\
\hline
\end{tabular}

5. Do you know the HIV status of your staff establishment?

\begin{tabular}{|l|l|l|l|}
\hline Yes & No & \\
\hline
\end{tabular}

If YES, please answer the following question. If $\mathrm{NO}$, please proceed to question 6 .

a. Approximately what percentage of your employees are HIV positive?

\begin{tabular}{|l|l|l|l|l|l|}
\hline $0 \%-10 \%$ & $11 \%-20 \%$ & $21 \%-30 \%$ & $31 \%-40 \%$ & $\begin{array}{l}41 \%- \\
50 \%\end{array}$ & $\begin{array}{l}51 \% \text { and } \\
\text { more }\end{array}$ \\
\hline
\end{tabular}

If NO:

6. How do you plan to measure HIV in your workplace?

\begin{tabular}{|l|l|}
\hline The organisation is conducting voluntary testing and counselling & \\
\hline Employees are encouraged to know and disclose their HIV status & \\
\hline Other, please specify & \\
\hline
\end{tabular}

SECTION B

This section explores your perceptions regarding the impact of HIVIAIDS on various aspects within your organisation. 
7. To what extent has HIVIAIDS impacted on each of the following skill levels in your organisation?

\begin{tabular}{|l|c|c|c|c|c|}
\hline & $\begin{array}{c}\text { TO NO } \\
\text { EXTENT }\end{array}$ & $\begin{array}{c}\text { TO A } \\
\text { SMALLER } \\
\text { EXTENT }\end{array}$ & $\begin{array}{c}\text { TO A } \\
\text { MODERATE } \\
\text { EXTENT }\end{array}$ & $\begin{array}{c}\text { TO A } \\
\text { LARGER } \\
\text { EXTENT }\end{array}$ & $\begin{array}{c}\text { TO A VERY } \\
\text { LARGE } \\
\text { EXTENT }\end{array}$ \\
\hline $\begin{array}{l}\text { No formal } \\
\text { education }\end{array}$ & 1 & 2 & 3 & 4 & 5 \\
\hline $\begin{array}{l}\text { Pre-matric } \\
\text { qualifications }\end{array}$ & 1 & 2 & 3 & 4 & 5 \\
\hline Matric & 1 & 2 & 3 & 4 & 5 \\
\hline Certificate & 1 & 2 & 3 & 4 & 5 \\
\hline Diploma & 1 & 2 & 3 & 4 & 5 \\
\hline $\begin{array}{l}\text { Degree/higher } \\
\text { qualification }\end{array}$ & 1 & 2 & 3 & 4 & 5 \\
\hline
\end{tabular}

8. To what extent has HIV/AIDS impacted negatively on/contributed negatively to each of the following in your organisation?

\begin{tabular}{|c|c|c|c|c|c|c|}
\hline \multirow{11}{*}{ 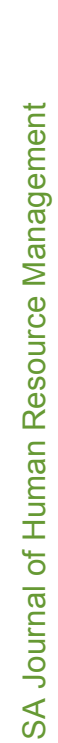 } & & $\begin{array}{l}\text { TO NO } \\
\text { EXTENT }\end{array}$ & $\begin{array}{c}\text { TO A } \\
\text { SMALLER } \\
\text { EXTENT }\end{array}$ & $\begin{array}{c}\text { TO A } \\
\text { MODERATE } \\
\text { EXTENT }\end{array}$ & $\begin{array}{c}\text { TO A } \\
\text { LARGER } \\
\text { EXTENT }\end{array}$ & $\begin{array}{c}\text { TO A } \\
\text { VERY } \\
\text { LARGE } \\
\text { EXTENT }\end{array}$ \\
\hline & Work performance & 1 & 2 & 3 & 4 & 5 \\
\hline & $\begin{array}{l}\text { Absenteeism due to } \\
\text { sick leave }\end{array}$ & 1 & 2 & 3 & 4 & 5 \\
\hline & Workload & 1 & 2 & 3 & 4 & 5 \\
\hline & Quality of output & 1 & 2 & 3 & 4 & 5 \\
\hline & $\begin{array}{l}\text { Absenteeism due to } \\
\text { funeral attendance }\end{array}$ & 1 & 2 & 3 & 4 & 5 \\
\hline & Overall productivity & 1 & 2 & 3 & 4 & 5 \\
\hline & Work unit productivity & 1 & 2 & 3 & 4 & 5 \\
\hline & $\begin{array}{l}\text { Output level of HIV- } \\
\text { positive employees }\end{array}$ & 1 & 2 & 3 & 4 & 5 \\
\hline & Service delivery & 1 & 2 & 3 & 4 & 5 \\
\hline & Customer satisfaction & 1 & 2 & 3 & 4 & 5 \\
\hline
\end{tabular}

9. To what extent do you agree with each of the following statements regarding the impact of HIVIAIDS on efficiency levels in your organisation?

\begin{tabular}{|l|c|c|c|c|c|}
\hline & $\begin{array}{l}\text { STRONGLY } \\
\text { DISAGREE }\end{array}$ & DISAGREE & NEUTRAL & AGREE & $\begin{array}{c}\text { STRONGLY } \\
\text { AGREE }\end{array}$ \\
\hline $\begin{array}{l}\text { HIV-positive } \\
\text { employees } \\
\text { are } \\
\text { transferred to } \\
\text { lighter duties }\end{array}$ & 1 & 2 & 3 & 4 & 5 \\
\hline $\begin{array}{l}\text { Employers } \\
\text { increase the } \\
\text { size of their } \\
\text { workforce } \\
\text { so that if } \\
\text { employees } \\
\text { become ill or } \\
\text { die, others } \\
\text { can step in } \\
\text { and take their } \\
\text { place }\end{array}$ & 1 & 2 & 3 & 4 & 5 \\
\hline
\end{tabular}

10. To what extent has HIVIAIDS impacted negatively on each of the following costs in your organisation?

\begin{tabular}{|l|c|c|c|c|c|}
\hline & $\begin{array}{c}\text { TO NO } \\
\text { EXTENT }\end{array}$ & $\begin{array}{c}\text { TO A } \\
\text { SMALLER } \\
\text { EXTENT }\end{array}$ & $\begin{array}{c}\text { TO } \\
\text { MODERATE } \\
\text { EXTENT }\end{array}$ & $\begin{array}{c}\text { TO A } \\
\text { LARGE } \\
\text { EXTENT }\end{array}$ & $\begin{array}{c}\text { TO A VERY } \\
\text { LARGE } \\
\text { EXTENT }\end{array}$ \\
\hline Overall labour costs & 1 & 2 & 3 & 4 & 5 \\
\hline HIV-related issues & 1 & 2 & 3 & 4 & 5 \\
\hline $\begin{array}{l}\text { Returns on } \\
\text { investment in terms } \\
\text { of training }\end{array}$ & 1 & 2 & 3 & 4 & 5 \\
\hline $\begin{array}{l}\text { Staff turnover } \\
\text { Costs of recruitment }\end{array}$ & 1 & 2 & 3 & 4 & 5 \\
\hline $\begin{array}{l}\text { Pre-employment } \\
\text { training cost }\end{array}$ & 1 & 2 & 3 & 4 & 5 \\
\hline $\begin{array}{l}\text { In-service training } \\
\text { to bring new } \\
\text { employees up to } \\
\text { level of old ones }\end{array}$ & 1 & 2 & 3 & 4 & 5 \\
\hline Production costs & 1 & 2 & 3 & 4 & 5 \\
\hline
\end{tabular}

11.To what extent has HIVIAIDS impacted negatively on each of the following aspects of competitiveness in your organisation?

\begin{tabular}{|l|c|c|c|c|}
\hline & $\begin{array}{c}\text { TO NO } \\
\text { EXTENT }\end{array}$ & $\begin{array}{c}\text { TO A SMALLER } \\
\text { EXTENT }\end{array}$ & $\begin{array}{c}\text { TO A MODERATE } \\
\text { EXTENT }\end{array}$ & $\begin{array}{c}\text { TO A LARGE } \\
\text { EXTENT }\end{array}$ \\
\hline Profit & 1 & 2 & 3 & 4 \\
\hline Prices & 1 & 2 & 3 & 4 \\
\hline Sales & 1 & 2 & 3 & 4 \\
\hline
\end{tabular}


APPENDIX B

SPSS item-total correlation statistics (questions 7-9)

\begin{tabular}{|c|c|c|c|c|c|}
\hline \multicolumn{6}{|c|}{ ITEM-TOTAL STATISTICS } \\
\hline & $\begin{array}{r}\text { SCALE MEAN IF ITEM } \\
\text { DELETED }\end{array}$ & $\begin{array}{r}\text { SCALE VARIANCE IF ITEM } \\
\text { DELETED }\end{array}$ & $\begin{array}{r}\text { CORRECTED ITEM-TOTAL } \\
\text { CORRELATION }\end{array}$ & $\begin{array}{r}\text { SQUARED MULTIPLE } \\
\text { CORRELATION }\end{array}$ & $\begin{array}{r}\text { CRONBACH'S ALPHA IF } \\
\text { ITEM DELETED }\end{array}$ \\
\hline Work performance & 23.64 & 30.354 & 0.712 & 0.663 & 0.875 \\
\hline Absenteeism due to sick leave & 23.65 & 30.001 & 0.685 & 0.694 & 0.876 \\
\hline Workload & 24.01 & 30.482 & 0.590 & 0.530 & 0.881 \\
\hline Quality of output & 24.23 & 31.492 & 0.503 & 0.493 & 0.885 \\
\hline $\begin{array}{l}\text { Absenteeism due to funeral } \\
\text { attendance }\end{array}$ & 24.02 & 29.508 & 0.674 & 0.637 & 0.876 \\
\hline Overall productivity & 24.27 & 29.479 & 0.689 & 0.740 & 0.875 \\
\hline Work unit productivity & 24.18 & 29.221 & 0.756 & 0.818 & 0.871 \\
\hline $\begin{array}{l}\text { Output level of HIV positive } \\
\text { employees }\end{array}$ & 23.99 & 28.588 & 0.757 & 0.657 & 0.870 \\
\hline Service delivery & 24.31 & 29.077 & 0.707 & 0.663 & 0.874 \\
\hline Customer satisfaction & 24.35 & 30.159 & 0.621 & 0.623 & 0.879 \\
\hline $\begin{array}{l}\text { HIV-positive employees are } \\
\text { transferred to lighter duties }\end{array}$ & 23.37 & 32.675 & 0.249 & 0.414 & 0.901 \\
\hline $\begin{array}{l}\text { Employers increase the size } \\
\text { of their workforce so that if } \\
\text { employees become ill or die, } \\
\text { others can step in and take } \\
\text { their place }\end{array}$ & 23.79 & 33.465 & 0.250 & 0.398 & 0.897 \\
\hline
\end{tabular}

Source: SPSS results

APPENDIX C

Interval descriptive statistics (questions 7-9)

\begin{tabular}{|c|c|c|c|c|c|}
\hline \multicolumn{6}{|c|}{ DESCRIPTIVE STATISTICS } \\
\hline $\begin{array}{l}\text { PERCENTAGE OF EMPLOYEES WHO ARE HIV } \\
\text { POSITIVE }\end{array}$ & & & & STATISTIC & STD. ERROR \\
\hline \multirow[t]{13}{*}{ Total } & Q7_9 & Mean & & 1.7409 & 0.0448 \\
\hline & & $95 \%$ confidence interval for mean & Lower bound & 1.6522 & \\
\hline & & & Upper bound & 1.8295 & \\
\hline & & $5 \%$ trimmed mean & & 1.7061 & \\
\hline & & Median & & 1.5833 & \\
\hline & & Variance & & 0.144 & \\
\hline & & Std. deviation & & 0.38000 & \\
\hline & & Minimum & & 1.08 & \\
\hline & & Maximum & & 3.33 & \\
\hline & & Range & & 2.25 & \\
\hline & & Interquartile range & & 0.29 & \\
\hline & & Skewness & & 1.895 & 0.281 \\
\hline & & Kurtosis & & 4.679 & 0.555 \\
\hline \multirow[t]{13}{*}{$0-10 \%$} & Q8_9 & Mean & & 1.9466 & 0.04889 \\
\hline & & $95 \%$ confidence interval for mean & Lower bound & 1.8488 & \\
\hline & & & Upper bound & 2.0444 & \\
\hline & & $5 \%$ trimmed mean & & 1.9195 & \\
\hline & & Median & & 1.8258 & \\
\hline & & Variance & & 0.148 & \\
\hline & & Std. deviation & & 0.38496 & \\
\hline & & Minimum & & 1.50 & \\
\hline & & Maximum & & 3.08 & \\
\hline & & Range & & 1.58 & \\
\hline & & Interquartile range & & 0.67 & \\
\hline & & Skewness & & 0.857 & 0.304 \\
\hline & & Kurtosis & & 0.099 & 0.599 \\
\hline
\end{tabular}


APPENDIX C (cont.)

\begin{tabular}{|c|c|c|c|c|c|}
\hline \multirow[t]{13}{*}{$11-20 \%$} & Q8_9 & Mean & & 2.2191 & 0.09182 \\
\hline & & $95 \%$ confidence interval for mean & Lower bound & 2.0304 & \\
\hline & & & Upper bound & 2.4079 & \\
\hline & & $5 \%$ trimmed mean & & 2.2135 & \\
\hline & & Median & & 2.2500 & \\
\hline & & Variance & & 0.228 & \\
\hline & & Std. deviation & & 0.47712 & \\
\hline & & Minimum & & 1.50 & \\
\hline & & Maximum & & 3.08 & \\
\hline & & Range & & 1.58 & \\
\hline & & Interquartile range & & 0.75 & \\
\hline & & Skewness & & -0.103 & 0.448 \\
\hline & & Kurtosis & & -1.059 & 0.872 \\
\hline \multirow[t]{13}{*}{$>\mathbf{2 0} \%$} & Q8_9 & Mean & & 2.4695 & 0.09185 \\
\hline & & $95 \%$ confidence interval for mean & Lower bound & 2.2824 & \\
\hline & & & Upper bound & 2.6566 & \\
\hline & & $5 \%$ trimmed mean & & 2.4484 & \\
\hline & & Median & & 2.4167 & \\
\hline & & Variance & & 0.278 & \\
\hline & & Std. deviation & & 0.52763 & \\
\hline & & Minimum & & 1.67 & \\
\hline & & Maximum & & 3.75 & \\
\hline & & Range & & 2.08 & \\
\hline & & Interquartile range & & 0.75 & \\
\hline & & Skewness & & 0.646 & 0.409 \\
\hline & & Kurtosis & & -0.167 & 0.798 \\
\hline
\end{tabular}

Source: SPSS results

APPENDIX D

SPSS interval descriptive statistics of the impact on labour and production costs (question 10)

\begin{tabular}{|c|c|c|c|c|c|}
\hline \multicolumn{6}{|c|}{ DESCRIPTIVE STATISTICS } \\
\hline $\begin{array}{l}\text { PERCENTAGE OF EMPLOYEES WHO ARE HIV } \\
\text { POSITIVE }\end{array}$ & & & & STATISTIC & STD. ERROR \\
\hline & Impact on costs & Mean & & 2.0616 & 0.07746 \\
\hline & & $95 \%$ confidence interval for mean & Lower bound & 1.9072 & \\
\hline & & & Upper bound & 2.2161 & \\
\hline & & $5 \%$ trimmed mean & & 1.9971 & \\
\hline & & Median & & 1.7500 & \\
\hline & & Variance & & 0.438 & \\
\hline & & Std. deviation & & 0.66181 & \\
\hline & & Minimum & & 1.00 & \\
\hline & & Maximum & & 4.38 & \\
\hline & & Range & & 3.38 & \\
\hline & & Interquartile range & & 0.50 & \\
\hline & & Skewness & & 1.786 & 0.281 \\
\hline & & Kurtosis & & 2.896 & 0.555 \\
\hline \multirow[t]{13}{*}{$0-10 \%$} & Impact on costs & Mean & & 2.4899 & 0.08995 \\
\hline & & $95 \%$ confidence interval for mean & Lower bound & 2.3100 & \\
\hline & & & Upper bound & 2.6698 & \\
\hline & & $5 \%$ trimmed mean & & 2.4498 & \\
\hline & & Median & & 2.5625 & \\
\hline & & Variance & & 0.502 & \\
\hline & & Std. deviation & & 0.70830 & \\
\hline & & Minimum & & 1.50 & \\
\hline & & Maximum & & 4.50 & \\
\hline & & Range & & 3.00 & \\
\hline & & Interquartile range & & 1.13 & \\
\hline & & Skewness & & 0.586 & 0.304 \\
\hline & & Kurtosis & & -0.197 & 0.599 \\
\hline
\end{tabular}


APPENDIX D (cont.)

\begin{tabular}{|c|c|c|c|c|c|}
\hline \multirow[t]{13}{*}{$11-20 \%$} & Impact on costs & Mean & & 2.8009 & 0.16058 \\
\hline & & $95 \%$ confidence interval for mean & Lower bound & 2.4708 & \\
\hline & & & Upper bound & 3.1310 & \\
\hline & & $5 \%$ trimmed mean & & 2.7978 & \\
\hline & & Median & & 2.7500 & \\
\hline & & Variance & & 0.696 & \\
\hline & & Std. deviation & & 0.83440 & \\
\hline & & Minimum & & 1.50 & \\
\hline & & Maximum & & 4.13 & \\
\hline & & Range & & 2.63 & \\
\hline & & Interquartile range & & 1.50 & \\
\hline & & Skewness & & 0.019 & 0.448 \\
\hline & & Kurtosis & & -1.350 & 0.872 \\
\hline \multirow[t]{13}{*}{$>\mathbf{2 0} \%$} & Impact on costs & Mean & & 3.3333 & 0.14327 \\
\hline & & $95 \%$ confidence interval for mean & Lower bound & 3.0415 & \\
\hline & & & Upper bound & 3.6252 & \\
\hline & & $5 \%$ trimmed mean & & 3.3483 & \\
\hline & & Median & & 3.6250 & \\
\hline & & Variance & & 0.677 & \\
\hline & & Std. deviation & & 0.82305 & \\
\hline & & Minimum & & 1.63 & \\
\hline & & Maximum & & 4.63 & \\
\hline & & Range & & 3.00 & \\
\hline & & Interquartile range & & 1.50 & \\
\hline & & Skewness & & -0.385 & 0.409 \\
\hline & & Kurtosis & & -1.147 & 0.798 \\
\hline
\end{tabular}

APPENDIX E

SPSS interval descriptive statistics of the impact on profit, prices and sales (question 11)

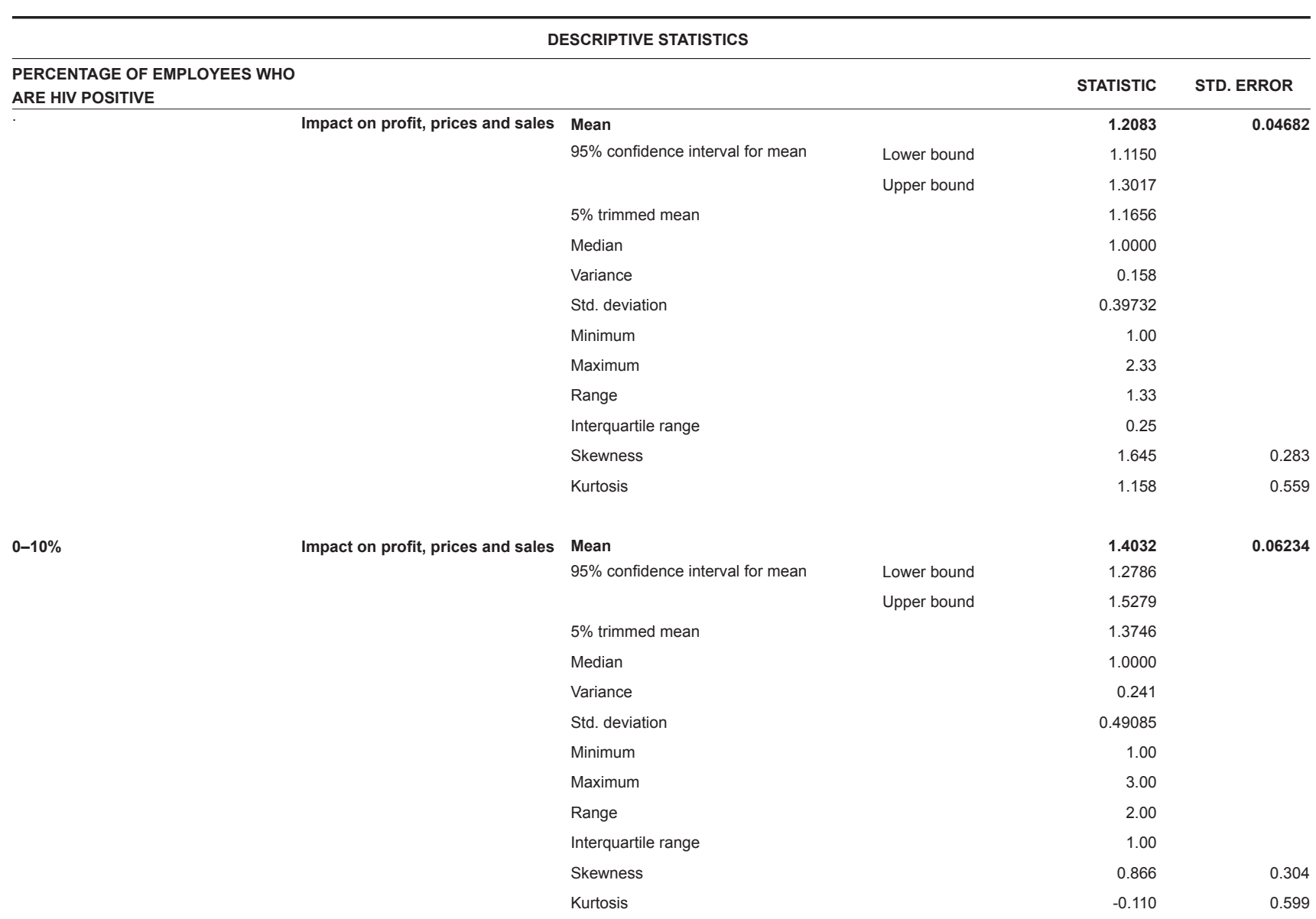


APPENDIX E (cont.)

\begin{tabular}{|c|c|c|c|c|c|}
\hline \multirow[t]{13}{*}{$11-20 \%$} & Impact on profit, prices and sales & Mean & & 1.4198 & 0.08642 \\
\hline & & $95 \%$ confidence interval for mean & Lower bound & 1.2421 & \\
\hline & & & Upper bound & 1.5974 & \\
\hline & & $5 \%$ trimmed mean & & 1.4108 & \\
\hline & & Median & & 1.3333 & \\
\hline & & Variance & & 0.202 & \\
\hline & & Std. deviation & & 0.44905 & \\
\hline & & Minimum & & 1.00 & \\
\hline & & Maximum & & 2.00 & \\
\hline & & Range & & 1.00 & \\
\hline & & Interquartile range & & 1.00 & \\
\hline & & Skewness & & 0.405 & 0.448 \\
\hline & & Kurtosis & & -1.715 & 0.872 \\
\hline \multirow[t]{13}{*}{$>\mathbf{2 0} \%$} & Impact on profit, prices and sales & Mean & & 1.8021 & 0.14188 \\
\hline & & $95 \%$ confidence interval for mean & Lower bound & 1.5127 & \\
\hline & & & Upper bound & 2.0914 & \\
\hline & & $5 \%$ trimmed mean & & 1.7454 & \\
\hline & & Median & & 2.0000 & \\
\hline & & Variance & & 0.644 & \\
\hline & & Std. deviation & & 0.80259 & \\
\hline & & Minimum & & 1.00 & \\
\hline & & Maximum & & 4.00 & \\
\hline & & Range & & 3.00 & \\
\hline & & Interquartile range & & 1.33 & \\
\hline & & Skewness & & 0.803 & 0.414 \\
\hline & & Kurtosis & & 0.145 & 0.809 \\
\hline
\end{tabular}

